\title{
First record of Scinax centralis (Anura, Hylidae) in the Triângulo Mineiro region, state of Minas Gerais, southeastern Brazil, with further data on its vocalization
}

\author{
Davi Lee Bang ${ }^{1,3,4}$; Marcio Pie ${ }^{2,5}$ \& Ariovaldo Antonio Giaretta ${ }^{1,6}$ \\ ${ }^{1}$ Universidade Federal de Uberlândia (UFU), Instituto de Ciências Exatas e Naturais do Pontal (ICENP), \\ Laboratório de Taxonomia e Sistemática de Anuros Neotropicais (LTSAN). Ituiutaba, MG, Brasil. \\ 2 Universidade Federal do Paraná (UFPR), Setor de Ciências Biológicas, Departamento de Zoologia (DZ00). Curitiba, PR, Brasil. \\ 3 Universidade de São Paulo (USP), Faculdade de Filosofia, Ciências e Letras de Ribeirão Preto (FFCLRP), Departamento de Biologia (DB), \\ Programa de Pós-Graduação em Biologia Comparada. Ribeirão Preto, SP, Brasil. \\ ${ }^{4}$ ORCID: http://orcid.org/0000-0002-5154-154X.E-mail: davileebang@yahoo.com.br (correspondence author) \\ ${ }^{5}$ ORCID: http://orcid.org/0000-0002-2949-4871. E-mail:marcio.pie@gmail.com \\ ${ }^{6}$ ORCID: http://orcid.org/0000-0001-7054-129X. E-mail: aagiaretta@gmail.com
}

\begin{abstract}
Scinax comprises more than 120 species which are split in two clades, the S. ruber and the S. catharinae clades. A few species within the $S$. catharinae clade occur in gallery forests of the Brazilian Cerrado. We here extend the distribution of S. centralis southwards based on new populations sampled in the banks of the Rio Paranaíba, in the borders of Minas Gerais (MG) and Goiás (GO) states, southeastern Brazil. We also provide further data on the species vocalization. Variation was seen among our population and topotypes regarding SVL and call dominant frequency, both likely representing a clinal variation. Our new population of $S$. centralis represents the first record of the species for the state of Minas Gerais.
\end{abstract}

Keywords. Atlantic Forest; Bioacoustics; Cerrado; Gallery forest; Geographic distribution.

\section{INTRODUCTION}

Scinax Wagler, 1830 is one of the most speciose genus of treefrogs of the Neotropics and it encompasses more than 120 species (Frost, 2021; Segalla et al., 2021). The genus is split in two clades, the $S$. ruber and the S. catharinae clades (sensu Faivovich, 2002). The S. catharinae clade harbors species which are distributed along the east, central, and central-west regions of Brazil, northeastern Argentina and southern Paraguay and Uruguay (Duellman et al., 2016; Frost, 2021). Most species of the $S$. catharinae clade occur in coastal forest environments, while a few occur in phytophysiognomies (e.g., gallery forests) of the Brazilian Cerrado biome, such as S. canastrensis (Cardoso \& Haddad, 1982), S. centralis Pombal \& Bastos, 1996, S. goya (Andrade et al., 2018), S. machadoi (Bokermann \& Sazima, 1973), S. pombali Lourenço, Carvalho, Baêta, Pezzuti \& Leite, 2013, S. skaios Pombal-Jr., Carvalho-Jr., Canelas \& Bastos, 2010, and Scinax sp. (Nogueira et al., 2016).

The aim of the present work is to extend the distribution of Scinax centralis southwards from its type locality, based on records from the banks of the Paranaíba River in the municipalities of Cumari and Araguari, states of Goiás (GO) and Minas Gerais (MG), respectively; we further provide data on calls from these populations.

\section{MATERIAL AND METHODS}

\section{Sampling and acoustic analysis}

Fieldwork was conducted within the municipalities of Cumari, GO (Fazenda Limoeiro, $18^{\circ} 22^{\prime} 51.00^{\prime \prime} \mathrm{S}, 48^{\circ} 06^{\prime} 59.00^{\prime \prime} \mathrm{W}, 586 \mathrm{~m}$ asl, WGS84 datum), and Araguari, MG (district of Amanhece, $18^{\circ} 25^{\prime} 22.70^{\prime \prime} \mathrm{S}, 48^{\circ} 11^{\prime} 43.40^{\prime \prime} \mathrm{W}, 590 \mathrm{~m}$ asl); even though at opposite sides of the Paranaíba River. These localities are less than $10 \mathrm{~km}$ apart one from each other. In both sites, males were found calling along sandy or rocky bottom streamlets $(<1 \mathrm{~m}$ wide) within forests.

Recordings were obtained with digital recorders (Marantz ${ }^{\circledast}$ PMD 671 and M-Audio Microtrack ${ }^{\ominus}$; set to 44.1 or $48.0 \mathrm{kHz}$ and 16- or 24-bit resolu- 
tion) with external directional microphones (Sennheiser ${ }^{\circ}$ K6/ME66 and ME67). Specimens and recordings are deposited in the amphibian collection of the Universidade Federal de Uberlândia (AAG-UFU), Uberlândia, Minas Gerais, Brazil (Appendices 1 and 2). We also examined specimens from the Célio F.B. Haddad collection $(\mathrm{CFBH}$, Universidade Estadual Júlio de Mesquita Filho, Rio Claro, state of São Paulo (SP)), and from the Universidade Federal de Goiás (ZUFG, Goiânia, GO) (Appendix 1) to ensure species identity. Twenty-six specimens from the populations sampled herein and twenty-one topotypes of Scinax centralis (ZUFG and CFBH), including five paratypes, had their snout-to-vent length (SVL) measured with digital calipers to the nearest $0.1 \mathrm{~mm}$.

Calls were analyzed in the Raven Pro 1.5 software (Center for Conservation Bioacoustics, 2014), with the following settings: Window Type = Hanning, Window Size $=256$ samples; $3 \mathrm{~dB}$ Filter Bandwidth $=270$ or 248 Hz; Overlap = 90\% (locked), Hop Size (temporal res- olution) $=0.542$ or $0.590 \mathrm{~ms}$, DFT Size $=1,024$ samples, Grid Spacing (spectral resolution) $=46.9$ or $43.1 \mathrm{~Hz}$. Calls were filtered up to $200-800 \mathrm{~Hz}$ to reduce background noise (wind and rain). The temporal variables were measured manually in the oscillogram and the spectral variables were obtained with automatic functions of Raven such as the 'Peak frequency' function. All other settings followed the software's default. Acoustic traits definitions and nomenclature are according to those adopted in Bang \& Giaretta (2017). Sound figures were made using the seewave package (Sueur et al., 2008) in the R v.3.1.2 platform (R Core Team, 2013) (settings = overlap of $90 \%$, and FFT window Hann and 256 samples).

Hepp et al. (2017) reviewed the calls of species of the Scinax catharinae clade and classified different notes as: (1) short squawk-like notes, (2) long squawk-like notes, and (3) click-like notes. They also classified calls according to the organization of note types, the main category classified as the type ' $A$ ' call (Fig. 1A), assumed as having
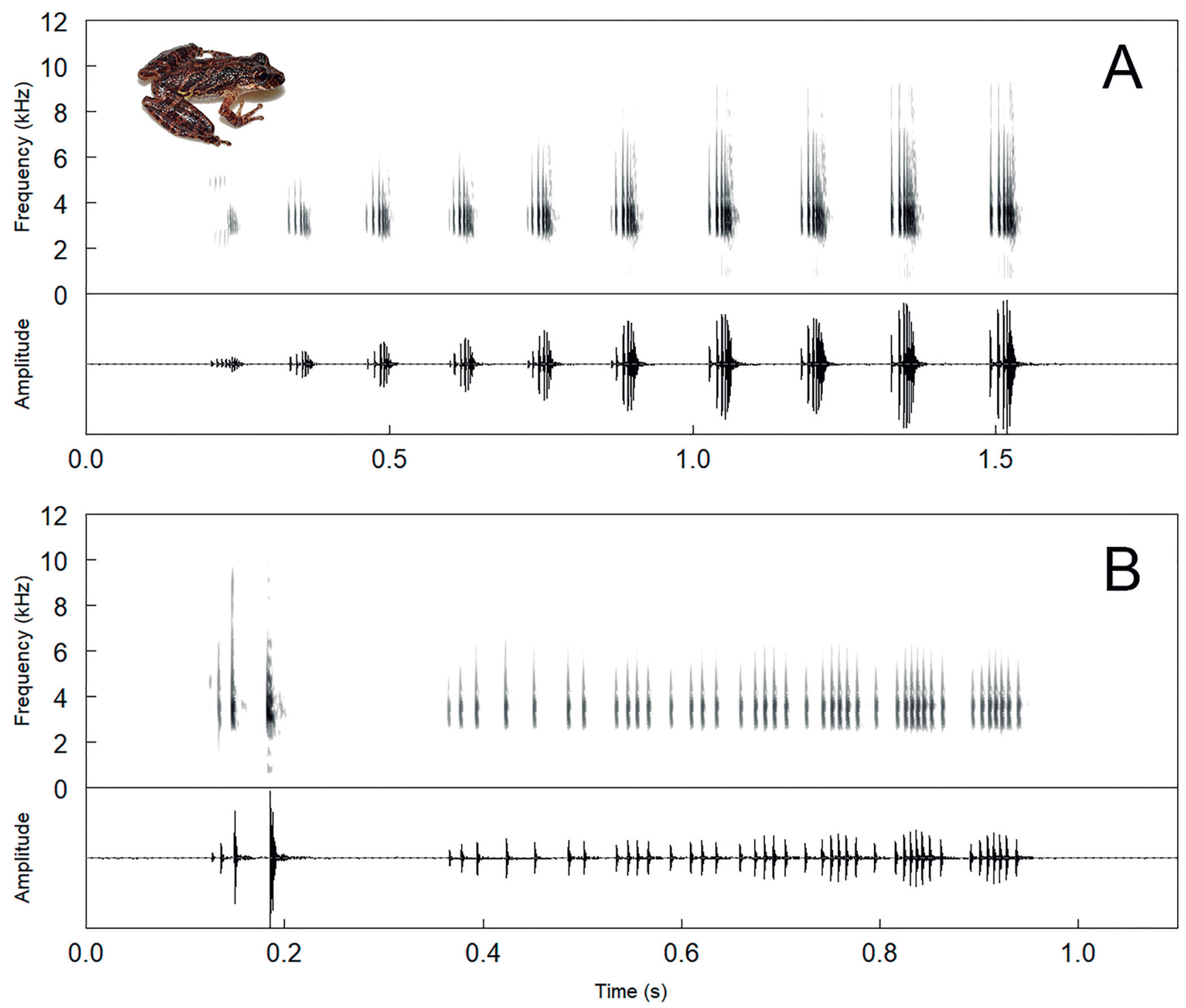

Figure 1. Spectrogram and its respective oscillogram of: (A) a type A (= advertisement) call of a male of Scinax centralis from Araguari, Triangulo Mineiro region, state of Minas Gerais, southeastern Brazil (sound file =Scinax_centralAraguariMG6bCBS_AAGmt; inset: a male individual (AAG-UFU 1822: 21.6 mm SVL)); and (B) a click-like note followed by a long squawk-like note (same sound file as in A). See further recording details in Appendix 2. Relative amplitudes in spectrogram figures have a grey scale in which black is the maximum amplitude $(0 \mathrm{~dB})$. 
Table 1. Acoustic traits for type A call (= advertisement; series of short squawk-like notes), long squawk- and click-like notes of Scinax centralis from Araguari (MG) and Cumari (G0), $\mathrm{n}=16$ males). Data are pooled and presented as mean (sd) minimum-maximum.

\begin{tabular}{|c|c|c|c|}
\hline Call traits & Type A call ( $n=99$ calls; 297 notes) & Long squawk ( $\mathrm{n}=52$ notes) & Click ( $n=66$ notes) \\
\hline Call duration (s) & $1.03(0.3) 0.56-1.49$ & - & - \\
\hline Note number & $9.74(2.92) 5.2-14.14$ & - & - \\
\hline Note rate (/s) & 8.96 (1.61) 6.87-13.14 & - & - \\
\hline Note duration (s) & $0.04(0.01) 0.02-0.05$ & $0.56(0.16) 0.05-1.12$ & $0.05(0.01) 0.03-0.09$ \\
\hline Pulse number & $9(1.3) 6-12$ & $61(17) 16-119$ & $7(2) 3-16$ \\
\hline Note 1 period (s) & $0.12(0.02) 0.07-0.15$ & - & - \\
\hline Note 2 period (s) & $0.11(0.02) 0.07-0.14$ & - & - \\
\hline Note 3 period (s) & $0.13(0.02) 0.09-0.17$ & - & - \\
\hline Pulse rate (/s) & 243 (49) 164-350 & $110(37) 46-186$ & $144(75) 42-372$ \\
\hline General dominant frequency $(\mathrm{Hz})$ & 3186 (283) 2559-3575 & 3174 (306) 2578-3703 & 3193 (329) 2297-3797 \\
\hline Dominant frequency of the $1^{\text {st }}$ note & 2805 (266) 2203-3321 & - & - \\
\hline Dominant frequency of the $2^{\text {nd }}$ note & 3080 (306) 2508-3462 & - & - \\
\hline Dominant frequency of the $3^{\text {rd }}$ note & $3160(290)$ 2559-3575 & - & - \\
\hline
\end{tabular}

an advertisement function, and consequently used in interspecific comparisons. We also could attribute the advertisement function to type A call based on comparisons with calls of other species of the S. catharinae clade already studied in a behavioral framework (Bastos et al., 2011; Bastos \& Haddad, 2002; Hepp et al., 2017). However, the classification of other call types ( $B$ and $C$ in Hepp et al. (2017)) were not followed, since other emission patterns were variable in an extent that precluded consistent classification.

\section{RESULTS}

\section{Species identification}

Specimens from Araguari (Fig. 1A) and Cumari were identified as Scinax centralis based on the following traits (Pombal-Jr. \& Bastos, 1996): subovoid or subeliptical rostrum in dorsal view, rounded in lateral view; evident canthus rostralis with a dark brown band; tympanum evident; interocular and triangular-shaped mark spot, with apex directed posteriorly; dorsum with grainy texture and two fused bands on a dark brown background that extend from the posterior ocular region to the inguinal region, forming an ' $X$ ' and with irregular blotches inside these bands; light bands present in flanks; the inguinal spots and the hidden regions of limbs have irregular blotches on a black background; exposed regions of limbs with a striped pattern with thick dark bars alternating with light lines; light beige belly with sparse pigmentations without a defined pattern; presence of a well-developed inguinal gland.

Our population had larger SVL of 21.4-29.9 mm (mean $=25.3 \mathrm{~mm}$, sd $=2.290, \mathrm{n}=26$ ), in contrast to the SVL of topotypes, which ranged from 18.1-22.7 mm (mean $=20.1, \mathrm{sd}=1.156, \mathrm{n}=21$ ).

\section{Acoustics}

The vocal repertoire of Scinax centralis ( $n=16$ males) from Araguari and Cumari consists of three types of notes: (1) short squawk-like (Fig. 1A), (2) long squawk-like
(Fig. 1B), and (3) click-like notes (Fig. 1B). These notes are emitted in different organizations, the main (most often emitted) type being classified as the call A (sensu Hepp et al. (2017); Fig. 1A), which is assumed as the advertisement call. Type A call consists of a sequence of short squawk-like notes that gradually increase in amplitude along the call, reaching maximum amplitude at its final portion. Each short squawk-like note within a call A also modulates in amplitude, gradually increasing and reaching its maximum amplitude in approximately half duration, decreasing to the end. Pulses within a note can have either full amplitude (i.e., separated by intervals) or incomplete (i.e., juxtaposed, commonly in the last portion of the note) modulations. Note period in the final portion of a call tends to be longer than those of initial and middle portions. The dominant frequency of the call slightly increases from the first to the last note. Descriptive statistics are summarized in Table 1.

Males also broadcast two other types of notes: the long squawk- and the click-like (Table 1, Fig. 1B). They are emitted sporadically, with no clear emission pattern compared to the type A call. Each note of the two can be emitted alone, in association with one another, or even in association with a type A call (shortly before or after it). The long squawk-like note is pulsed (pulses can be or not arranged in groups) and can have variable durations. This note can have a longer first portion with low amplitude, followed by an increase in amplitude in its last third of duration, decreasing until the end of the note. The clicklike note is also pulsed and resembles a short squawklike note, but with more irregularly organized pulses (usually the last pulses are more juxtaposed), resulting in lower pulse repetition rates. Click-like notes can be emitted alone or in groups of 2-8 notes, in association or not with a long squawk-like note or a type A call. Descriptive statistics of each note in Table 1.

\section{DISCUSSION}

Advertisement calls from our populations match those of topotypes Scinax centralis (Bastos et al., 2011) and some other species of the S. catharinae clade (Bang 


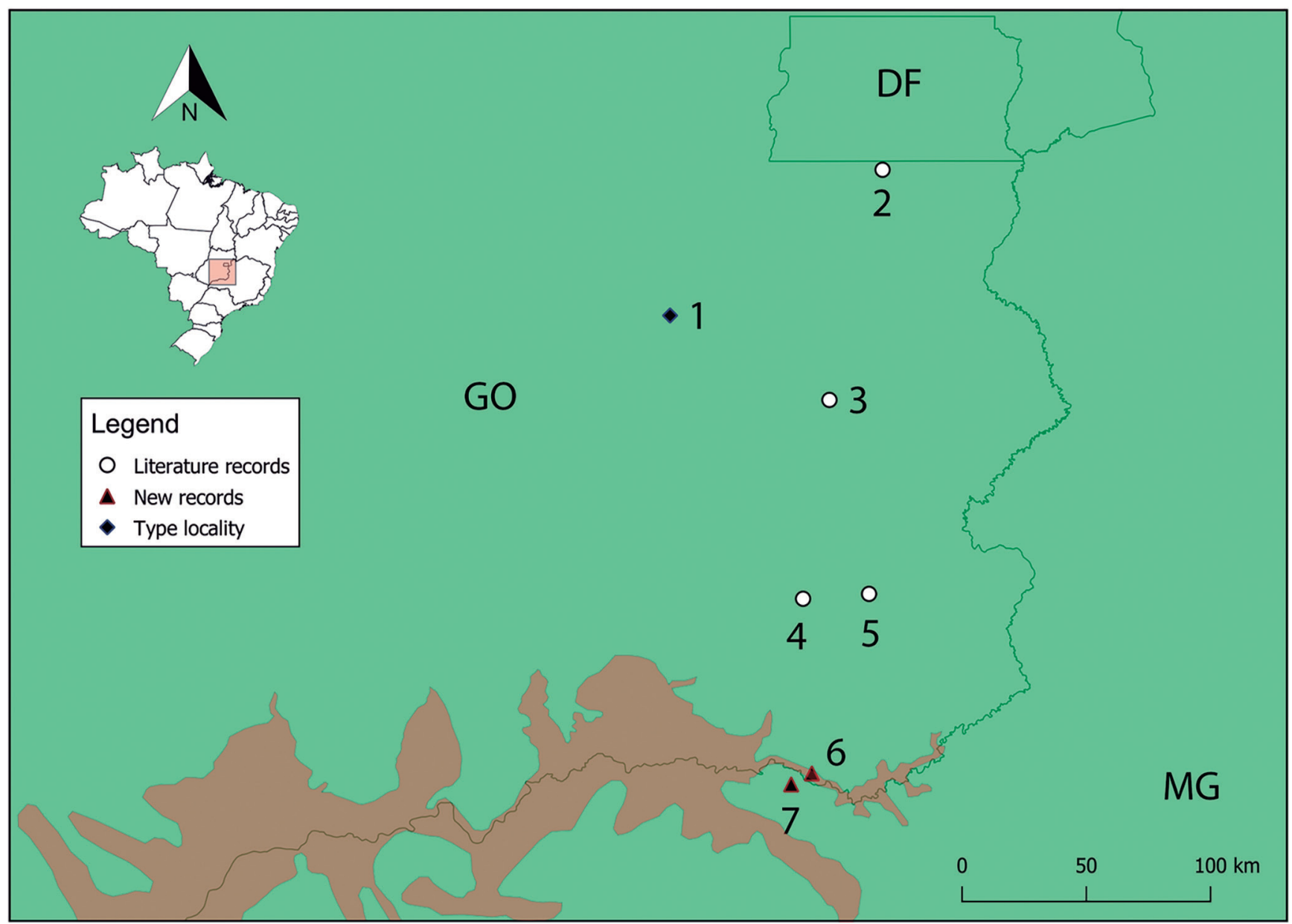

Figure 2. Map of distribution of Scinax centralis. (1) Floresta Nacional de Silvânia, Silvânia; (2) Mesquita stream, Brasília; (3) Córrego do Fogo, Orizona; (4) Ipameri; (5) Mariquita stream, Campo Alegre de Goiás; (6) Fazenda Limoeiro, Cumari; (7) District of Amanhece, Araguari. Abbreviations for Brazilian states: DF = Distrito Federal, $G 0=$ Goiás, MG = Minas Gerais. Literature records from Moura et al. (2010). Region in faded pink represents the Atlantic Forest biome.

\& Giaretta, 2017; Hepp et al., 2017) in relation to the general structure of type A call, which is composed by a series of short squawk-like notes that increase in amplitude along the call, and also in relation to the emission of long squawk- and click-like notes. However, prominent differences were found between our population and topotypes in dominant frequency (3.49-4.89 kHz, mean $=4.16$, sd = 0.37; Bastos et al., 2011) and SVL, topotypes being smaller. An inverse relationship between SVL and call dominant frequency is well known to frogs (Wells, 2007) and it seems to exist in our data as well, as males from our populations had larger sizes and lower frequency calls. This negative relationship between SVL and call frequency was examined for $S$. centralis by Bastos et al. (2011). Moreover, the emission of long squawk-like notes shortly after the emission of a type A call probably acts in both female attraction (A calls) and aggressiveness to neighboring males (long squawk-like notes) in a single vocalization effort (Larson, 2004; Pereyra et al., 2012).

Reports on Scinax centralis occurrences outside type locality includes southern localities such as Campo Alegre de Goiás and Orizona (both GO; Fig. 2; Moura et al., 2010). It is possible that the differences we found for SVL and some call traits between populations may represent a clinal variation (Foster \& Endler, 1999), as seen to other frog groups (Ryan et al., 1996; Pröhl et al., 2007). In conclusion, our record represents the first occurrence of S. centralis to the Triângulo Mineiro region, in the state of Minas Gerais, in a fragment of the Atlantic Forest biome (Fig. 2), extending the species distribution southwards in $\sim 75 \mathrm{~km}$ from the previously southernmost record.

\section{ACKNOWLEDGEMENTS}

Katia G. Facure first called our attention to the existence of the southern population of Scinax centralis in Araguari. Cyro B. de Sousa helped in the fieldwork. Frederico G. Lemos allowed access to his property and provided facilities. Célio F.B. Haddad allowed the examination of specimens under his care. FNJV allowed access to the recordings of the species type locality. Collection permits by ICMBio/SISBIO (\#30059). The Cornell Lab of Ornithology provided a free license of Raven Pro Software.

\section{AUTHORS' CONTRIBUTIONS}

DLB, MP and AAG conceived this study and wrote the first drafts of this paper. AAG collected data. DLB and AAG conducted morphometric and acoustic analysis. DLB, MP and $A A G$ read and reviewed drafts of this manuscript. 


\section{CONFLICTS OF INTEREST}

None.

\section{FUNDING INFORMATION}

Financial support by Conselho Nacional de Desenvolvimento Científico e Tecnológico (CNPq) to AAG lab (\#446935/2014-0). Research grants to AAG (\#300903/2015-4 and \#305169/2019-0) and MP (\#301636/2016-8) by CNPq. This work is part of the Master dissertation of DLB, which was funded by CNPq (process \#159817/2015-3). Fundação de Amparo à Pesquisa do Estado de São Paulo (FAPESP) currently provides a PhD fellowship to DLB (process \#2017/27137-7).

\section{REFERENCES}

Andrade, S.P.; Santos, D.L.; Rocha, C.F.; Pombal-Jr., J.P. \& Vaz-Silva, W. 2018. A new species of the Ololygon catharinae species group (Anura: Hylidae) from the Cerrado biome, State of Goiás, Central Brazil. Zootaxa, 4425(2): 283-303. DOI

Bang, D.L. \& Giaretta, A.A. 2017. A reassessment of the vocalizations of three species of Ololygon (Anura: Hylidae) from southeastern Brazil. Phyllomedusa: Journal of Herpetology, 16(1): 23-45. D0I

Bastos, R.P. \& Haddad, C.F. 2002. Acoustic and aggressive interactions in Scinax rizibilis (Anura: Hylidae) during the reproductive activity in southeastern Brazil. Amphibia-Reptilia, 23(1): 97-104. https://brill.com/ view/journals/amre/23/1/article-p93 8.xml.

Bastos, R.P.; Alcantara, M.B.; Morais, A.R.; Lingnau, R. \& Signorelli, L. 2011. Vocal behaviour and conspecific call response in Scinax centralis. The Herpetological Journal, 21(1): 43-50. https://www.thebhs.org/ publications/the-herpetological-journal/volume-21-number-1january-2011/609-06-vocal-behaviour-and-conspecific-call-responsein-i-scinax-centralis-i.

Bokermann, W.C.A. \& Sazima, I. 1973. Anfíbios da Serra do Cipó, Minas Gerais, Brasil. 1: Duas espécies novas de Hyla (Anura, Hylidae). Revista Brasileira de Biologia, 33(4): 521-528.

Cardoso, A.J. \& Haddad, C.F.B. 1982. Nova espécie de Hyla da Serra da Canastra (Amphibia, Anura, Hylidae). Revista Brasileira de Biologia, 42(3): 499-503.

Center for Conservation Bioacoustics. 2014. Raven Pro: Interactive Sound Analysis Software (Version 1.5). The Cornell Lab of Ornithology Ithaca (NY). Available: https://ravensoundsoftware.com/software/raven-pro.

Duellman, W.E.; Marion, A.B. \& Hedges, S.B. 2016. Phylogenetics, classification, and biogeography of the treefrogs (Amphibia: Anura: Arboranae). Zootaxa, 4104(1): 1-109. D01
Faivovich, J. 2002. A cladistic analysis of Scinax (Anura: Hylidae). Cladistics, 18(4): 367-393

Foster, S.A. \& Endler, J.A. 1999. Geographic variation in behavior: perspectives on evolutionary mechanisms. New York, Oxford University Press.

Frost, D.R. 2021. Amphibian Species of the World: an Online Reference. Version 6.1. New York, American Museum of Natural History. Available: https://amphibiansoftheworld.amnh.org.

Hepp, F.; Lourenço, A.C.C. \& Pombal-Jr., J.P. 2017. Bioacoustics of four Scinax species and a review of acoustic traits in the Scinax catharinae species group (Amphibia: Anura: Hylidae). Salamandra, 53(2): 212-230. https://www.salamandra-journal.com/index.php/home/ contents/2017-vol-53/1825-hepp-f-a-c-c-lourenco-j-p-pombal-jr.

Larson, K.A. 2004. Advertisement call complexity in northern leopard frogs, Rana pipiens. Copeia, 2004(3): 676-682.

Moura, M.; Gasparini, J. \& Feio, R. 2010. Amphibia, Anura, Hylidae, Scinax centralis Pombal and Bastos, 1996: distribution extension, geographic distribution map. Check List, 6: 173. DOI

Nogueira, L.; Sole, M.; Siqueira, S.; Affonso, P.R.; Strussmann, C. \& Sampaio, I. 2016. Genetic analysis reveals candidate species in the Scinax catharinae clade (Amphibia: Anura) from Central Brazil. Genetics and Molecular Biology, 39(1): 49-53. D01

Pereyra, M.0.; Borteiro, C.; Baldo, D.; Kolenc, F. \& Conte, C.E. 2012. Advertisement call of the closely related species Scinax aromothyella Faivovich, 2005 and S. berthae (Barrio, 1962), with comments on the complex calls in the S. catharinae groups. The Herpetological Journal, 22(2): 133-137.

Pombal-Jr., J.P. \& Bastos, R.P. 1996. Nova espécie de Scinax Wagler, 1830 do Brasil Central (Amphibia, Anura, Hylidae). Boletim do Museu Nacional de Zoologia, Rio de Janeiro, 371: 1-11.

Pombal-Jr., J.P.; Carvalho-Jr., R.R.; Canelas, M.A.S. \& Bastos, R.P. 2010. A new Scinax of the $S$. catharinae species group from Central Brazil (Amphibia: Anura: Hylidae). Zoologia, Curitiba, 27(5): 795-802. D0I

Pröhl, H.; Hagemann, S.; Karsch, J. \& Höbel, G. 2007. Geographic variation in male sexual signals in strawberry poison frogs (Dendrobates pumilio). Ethology, 113(9): 825-837. DOI

R Core Team. 2013. R: A language and environment for statistical computing. Available: https://www.r-project.org.

Ryan, M.J.; Rand, A.S. \& Weigt, L.A. 1996. Allozyme and advertisement call variation in the túngara frog, Physalaemus pustulosus. Evolution, 50(6): 2435-2453. DOI

Segalla, M.V.; Berneck, B.; Canedo, C.; Caramaschi, U.; Cruz, C.A.G.; Garcia, P.C.A.; Grant, T.; Haddad, C.F.B.; Lourenço, A.C.C.; Mângia, S.; Mott, T.; Nascimento, L.B.; Toledo, L.F.; Werneck, F.P. \& Langone, J.A. 2021. List of Brazilian Amphibians. Herpetologia Brasileira, 10(1): 121-216.

Sueur, J.; Aubin, T. \& Simonis, C. 2008. Seewave, a free modular tool for sound analysis and synthesis. Bioacoustics, 18(2): 213-226.

Wells, K.D. 2007. The ecology and behavior of amphibians. Chicago, University of Chicago Press. 


\section{APPENDIX 1}

\section{List of analyzed specimens. Paratypes numbers in bold.}

Scinax centralis from Araguari and Cumari: BRASIL, Minas Gerais: Araguari, Amanhece (AAG-UFU 1800-1805, 1819-1824, 5202); Goiás: Cumari, Fazenda Limoeiro (AAG-UFU 1807-1808, 1185-1194, 458-461, 947).

Scinax centralis topotypes: BRASIL, Goiás: Floresta Nacional de Silvânia (CFBH 4424-4426, 4503, 4169, 2640-2644, ZUFG 1062, 1074, 174, 1065, 1067, 853, 3156, 3210, 3241-3242, 368).

\section{APPENDIX 2}

\section{List of analyzed sound files with associated metadata. Labels such as '1a-e' indicate} the number of the recorded individual and its different sampled sections.

\begin{tabular}{lccc}
\hline \multicolumn{1}{c}{ Locality } & Date & Air $\left({ }^{\circ} \mathrm{C}\right)$ & Voucher \\
\hline Araguari (MG) & & & \\
Scinax_centralAraguariMG1a-eAAGm671 & $17-18 / 08 / 2013$ & 17 & - \\
Scinax_centralAraguariMG2a-dAAGm671 & $01 / 09 / 2013$ & 19 & AAG-UFU 1819 \\
Scinax_centralAraguariMG4a-dAAGm671 & $01 / 09 / 2013$ & 11 & AAG-UFU 1824 \\
Scinax_centralAraguariMG5aCBS_AAGmt & $01 / 09 / 2013$ & 11 & AAG-UFU 1822 \\
Scinax_centralAraguariMG6a-bCBS_AAGmt & $01 / 09 / 2013$ & 11 & AAG-UFU 1823 \\
Scinax_centralAraguariMG7aCBS_AAGmt & $01 / 09 / 2013$ & 11 & AAG-UFU 1821 \\
Scinax_centralAraguariMG8a-CAAGm671 & $01 / 09 / 2013$ & 17 & - \\
Cumari (G0) & & & \\
Scinax_centralCumariG01a-bAAGmt & $26 / 06 / 2011$ & 15 & AAG-UFU 458 \\
Scinax_centralCumariG02aAAGmt & $26 / 06 / 2011$ & 15 & AAG-UFU 459 \\
Scinax_centralCumariG03aAAGmt & $26 / 06 / 2011$ & 15 & - \\
Scinax_centralCumariG04aAAGmt & $26 / 06 / 2011$ & 15 & - \\
Scinax_centralCumariG05aAAGmt & $26 / 06 / 2011$ & 16 & - \\
Scinax_centralCumariG07a-cAAGm671 & $04 / 09 / 2011$ & 25 & - \\
Scinax_centralCumariG010a-0AAGm & $06 / 09 / 2012$ & 14 & AAG-UFU 1185 \\
Scinax_centralCumariG012a-cAAGm671 & $04 / 09 / 2013$ & 10 & - \\
Scinax_centralCumariG013a-cAAGm671 & $04 / 09 / 2013$ & 10 & - \\
\hline
\end{tabular}

